\title{
EVALUASI NUTRISI PERBEDAAN RASIO DEDAK PADI DAN AMPAS BIR DITINJAU DARI NILAI TDN RANSUM DOMBA LOKAL JANTAN
}

\author{
T. Saputro, S. D. Widyawati dan Suharto \\ Program Studi Peternakan, Fakultas Pertanian, Universitas Sebelas Maret, Surakarta \\ Email: susidwiwidyawati@yahoo.co.id
}

\begin{abstract}
ABSTRAK
Penelitian ini bertujuan untuk mengetahui pengaruh pemberian dedak padi (DP) dan limbah industri bir atau ampas bir (AB) dengan rasio berbeda terhadap nilai TDN ransum domba lokal serta mengetahui level pemberian yang optimal. Domba yang digunakan dalam penelitian ini adalah domba lokal jantan dengan bobot badan $15 \mathrm{~kg} \pm 1,5 \mathrm{~kg}$ sebanyak 12 ekor. Ransum perlakuan terdiri dari hijauan dan konsentrat dengan perbandingan 60\% : 40\% (dalam BK) yang berupa rumput raja, DP dan AB. Rancangan yang digunakan dalam penelitian ini adalah Rancangan Acak Kelompok (RAK) dengan 3 perlakuan dan 4 ulangan. Perlakuan yang diterapkan adalah P1 $=60 \%$ Rumput Raja $+29 \%$ DP $+9 \%$ AB + $2 \%$ Premix, P2 $=60 \%$ Rumput Raja $+19 \%$ DP $+19 \%$ AB $+2 \%$ Premix, P3 $=60 \%$ Rumput Raja $+9 \%$ DP $+29 \% \mathrm{AB}+2 \%$ Premix. Peubah yang diamati adalah nutrien (protein kasar=PK, lemak kasar=LK, serat kasar=SK dan bahan ekstrak tiada Nitrogen=BETN) dapat dicerna. Hasil penelitian menunjukkan bahwa PKdd dan LKdd sangat dipengaruhi $(\mathrm{P}<0.01)$ oleh rasio perbandingan DP dan AB. Penggunaan rasio 19\% DP : 19\% AB dan 9\% DP : 29\% AB sangat nyata meningkatkan PKdd dan LKdd (PK dd : 6.71 vs 7.64; 8.12 dan LKdd : 4.07 vs 4.27; 4.36). Sedangkan karbohidrat yang terdiri dari SKdd dan BETNdd tidak dipengaruhi oleh perbedaan rasio DP dan AB. Penggunaan dedak padi dan ampas bir pada domba lokal jantan memberikan nilai TDN terbaik pada level 19\% dedak padi dan 19\% ampas bir.
\end{abstract}

Kata kunci : Domba lokal, dedak padi, ampas bir, nutrien dapat dicerna, TDN ransum

\section{Nutritional Evaluation of Differences Ratio of Rice Bran and By-Product of Beer on TDN of Local Sheep Ration}

\begin{abstract}
This study aimed to determine the effect of rice bran (DP) and industrial waste beer or beer dregs (AB) with different ratios on TDN local sheep ration and to know the optimal level of provision. Sheep were used in this study were male local sheep weighing $15 \mathrm{~kg} \pm 1.5 \mathrm{~kg}$ as much as 12 heads. Treatment ration consists of forage and concentrates with a ratio of 60\%: 40\% (in DM) in the form of grass king, DP and $\mathrm{AB}$. The design used in this study is a Completely Randomized Block Design (RCBD) with three treatments and four replications. Treatment applied is P1 $=60 \%$ Grass King $+29 \% \mathrm{DP}+9 \% \mathrm{AB}+2 \%$ Premix, P2 $=60 \%$ Grass King $+19 \%$ DP $+19 \%$ AB $+2 \%$ Premix, P3 $=60 \%$ Grass King $+9 \%$ DP + $29 \% \mathrm{AB}+2 \%$ Premix. Variables measured are nutrients (crude protein $=\mathrm{PK}$, extract ether $=\mathrm{LK}$, crude fiber $=$ SK and Nitrogen free extract $=$ BETN) can be digested. The results showed that PKdd and LKdd strongly influenced $(\mathrm{P}<0.01)$ by the ratio of $\mathrm{DP}$ and $\mathrm{AB}$. The use of $\mathrm{DP}$ and $\mathrm{AB}$ ratio of 19\%: $19 \%$ and 9\% DP AB : 29\% highly significant to increase PKdd and LKdd (PK ss: 6.71 vs 7.64; 8.12 and the LKdd: 4:07 vs $4: 27 ; 4: 36)$. While carbohydrates are composed of SKdd and BETNdd did not influenced by differences in the ratio of DP and AB. The use of rice bran and the dregs of beer at local male sheep give the best TDN value at the level of $19 \%$ and $19 \%$ rice bran and industrial waste beer or beer dregs.
\end{abstract}

Keywords : Sheep, rice bran, industrial waste beer, digestible nutrients, TDN 


\section{PENDAHULUAN}

Domba lokal merupakan salah satu jenis ternak penghasil daging yang memiliki keunggulan, diantaranya adalah mudah pemeliharaannya, cepat berkembang biak dan memiliki daya adaptasi yang tinggi terhadap kondisi alam di Indonesia. Peningkatan produktifitas domba lokal sebagai penghasil daging dipengaruhi oleh menajemen pemeliharaan yang baik, terutama manajemen pakan. Sistem pemeliharaan ternak domba di Indonesia mayoritas masih dilakukan secara tradisional dengan pemberian pakan hijauan saja. Pemberian pakan hijauan belum cukup untuk memenuhi kebutuhan nutrien pada domba, ditambah lagi saat musim kemarau kualitas hijauan menjadi menurun sehingga perlu diimbangi dengan pemberian pakan konsentrat.

Konsentrat merupakan pakan penguat yang diberikan untuk melengkapi kebutuhan nutrien yang ada dalam pakan utama. Pengadaan konsentrat dalam pemeliharaan ternak domba sering menimbulkan kendala karena harganya yang mahal, sehingga perlu mencari bahan pakan dengan harga murah, tidak dikonsumsi oleh manusia, mudah didapat, ketersediaan banyak, tidak beracun dan mempunyai nili gizi yang cukup baik dalam penyusunan ransum. Salah satunya dengan memanfaatkan hasil limbah pertanian maupun industri seperti dedak padi dan ampas bir.

Dedak padi adalah hasil samping dari proses penggilingan padi menjadi beras yang merupakan bahan pakan sumber energi dimana dapat digunakan sebagai pakan penguat bagi ternak domba. Creswell (1987) melaporkan bahwa hasil analisis dari 4 sampel dedak padi yang berasal dari Indonesia memiliki kandungan protein kasar dengan kisaran 12,7-13,5\%, lemak 10,6-13,6\% dan serat kasar $8,2-12,2 \%$. Penggunaan dedak padi dalam ransum perlu dicampur dengan ampas bir untuk melengkapi kebutuhan protein. Ampas bir adalah limbah industri pembuatan bir yang menggunakan barley dan bahan lain berkadar maltosa tinggi sebagai bahan utama. Menurut Andriyani (2006) ampas bir mengandung bahan kering (BK) 18,89\%, protein kasar (PK) 19,31\%, serat kasar (SK) $19,48 \%$, dan total digestible nutrient (TDN) $69,89 \%$.

Perpaduan dari dedak padi sebagai bahan pakan sumber energi, serta ampas bir dengan kandungan protein diharapkan dapat memenuhi kebutuhan nutrient domba dan mengoptimalakan pertumbuhan mikrobia rumen. Meningkatnya populasi dan aktivitas mikrobia rumen dapat meningkatkan kecernaan, meningkatkan konsumsi pakan dan akhirnya meningkatkan produktivitas ternak domba. Atas pertimbangan tersebut maka dilakukan penelitian tentang pengaruh pemberian dedak padi dan ampas bir dengan rasio berbeda terhadap nilai TDN ransum pada domba lokal.

\section{MATERI DAN METODE}

Penelitian ini dilaksanakan di Kandang Percobaan milik Program studi Peternakan Fakultas Pertanian UNS di Desa Jatikuwung, Kecamatan Gondangrejo, Kabupaten Karanganyar. Analisis bahan pakan dilaksanakan di Laboratorium Nutrisi dan Makanan Ternak, Jurusan Peternakan Fakultas Pertanian UNS.

Domba yang digunakan dalam penelitian ini adalah domba lokal jantan dengan bobot badan $15 \mathrm{~kg} \pm 1,5 \mathrm{~kg}$ sebanyak 12 ekor. Domba sebanyak 12 ekor dibagi tiga perlakuan tiap perlakuan terdiri empat ulangan dan setiap ulangan terdiri dari satu ekor domba.

Tabel 1. Kebutuhan nutrien domba $15 \mathrm{~kg}$

\begin{tabular}{lr}
\hline \hline Nutrien & \multicolumn{1}{c}{ Jumlah } \\
\hline Energi (TDN) & $67,85 \%$ \\
Protein Kasar & $8,7 \%$ \\
Kalsium & $0,51 \%$ \\
Fosfor & $0,25 \%$ \\
\hline
\end{tabular}

Sumber: Kearl (1982) 
Tabel 2. Kandungan nutrien bahan pakan penyusun ransum

\begin{tabular}{llrrrrrr}
\hline Bahan pakan & BK & \multicolumn{1}{l}{ PK } & SK & LK & ABU & BETN $^{3}$ & TDN $^{4}$ \\
\cline { 3 - 8 } & $\%$ & & ------------------ & \%BK & --------------------- & \\
\hline Rumput raja $^{1}$ & 21,91 & 7,88 & 36,34 & 4,71 & 15,29 & 35,78 & $54,82^{\mathrm{a}}$ \\
Dedak padi $^{2}$ & 90,40 & 9,90 & 19,80 & 4,90 & 14,70 & 50,70 & $57,82^{\mathrm{b}}$ \\
Ampas bir $^{1}$ & 25,90 & 18,62 & 19.20 & 6,10 & 23,70 & 32,38 & $47.80^{\mathrm{c}}$ \\
\hline
\end{tabular}

Sumber : 1. Laboratorium Nutrisi dan Makanan Ternak Jurusan Peternakan, Fakultas Pertanian Universitas Sebelas Maret Surakarta

2. Hartadi et al., (1980)

3. $\mathrm{BETN}=100-(\mathrm{PK}+\mathrm{SK}+\mathrm{LK}+\mathrm{ABU})$

4. Berdasarkan rumus persamaan-persamaan regresi untuk memperkirakan total digestible nutrient sesuai rumus Hartadi et al., (1980)

a) $\operatorname{TDN}(\%)=-26,685+1,334(\mathrm{SK})+6,598(\mathrm{LK})+1,423(\mathrm{BETN})+0,967(\mathrm{PK})-$ $0,002(\mathrm{SK})^{2}-0,670(\mathrm{LK})^{2}-0,024(\mathrm{SK})(\mathrm{BETN})-0,055(\mathrm{LK})(\mathrm{BETN})-0,146$ (LK) $(\mathrm{PK})+0,039(\mathrm{LK})^{2}(\mathrm{PK})$

b) $\operatorname{TDN}(\%)=22,822-1,440(\mathrm{SK})-2,875(\mathrm{LK})+0,655(\mathrm{BETN})+0,863(\mathrm{PK})+$ $0,020(\mathrm{SK})^{2}-0,078(\mathrm{LK})^{2}+0,018(\mathrm{SK})(\mathrm{BETN})+0,045(\mathrm{LK})(\mathrm{BETN})-0,085$ (LK) $(\mathrm{PK})+0,020(\mathrm{LK})^{2}(\mathrm{PK})$

c) $\operatorname{TDN}(\%)=-54,820+1,951(\mathrm{SK})+0,601(\mathrm{LK})+1,602(\mathrm{BETN})+1,324(\mathrm{PK})-$ $0,027(\mathrm{SK})^{2}+0,032(\mathrm{LK})^{2}-0,021(\mathrm{SK})(\mathrm{BETN})+0,018(\mathrm{LK})(\mathrm{BETN})+0,035$ $(\mathrm{LK})(\mathrm{PK})-0,0008(\mathrm{LK})^{2}(\mathrm{PK})$

Ransum perlakuan yang digunakan terdiri dari rumput raja, dedak padi dan ampas bir. Kebutuhan nutrien domba, kandungan nutrisi bahan pakan penyusun ransum dan susunan perlakuan serta kandungan nutrient ransum perlakuan berturut-turut pada Tabel 1 , Tabel 2 dan Tabel 3. Pemix diberikan 2\% dari kebutuhan bahan kering.

Kandang yang digunakan dalam penelitian ini merupakan kandang individu dengan sistem panggung yang berjumlah 12 buah, berukuran $1,2 \mathrm{~m} \times 0,75 \mathrm{~m}$ untuk tiap ekor.

Desain penelitian menggunakan Rancangan Acak Kelompok (RAK) dengan tiga perlakuan. Masing-masing perlakuan diulang empat kali sebagai blok dan setiap blok terdiri dari tiga ekor domba lokal jantan. Adapun perlakuan yang diberikan :

$\mathrm{P} 1=60 \%$ Rumput Raja $+29 \%$ Dedak Padi + 9\% Ampas Bir $+2 \%$ Premix

P2 $=60 \%$ Rumput Raja $+19 \%$ Dedak Padi + $19 \%$ Ampas Bir $+2 \%$ Premix
P3 $=60 \%$ Rumput Raja $+9 \%$ Dedak Padi + $29 \%$ Ampas Bir $+2 \%$ Premix

Peubah yang diamati meliputi protein kasar dapat dicerna (PKdd), serat kasar dapat dicerna (SKdd), lemak kasar dapat dicerna (LKdd), bahan ekstrak tanpa nitrogen dapat dicerna (BETNdd) dan total digestible nutrient (TDN).

Pelaksanaan penelitian terdiri tiga tahap yaitu tahap adaptasi dan tahap koleksi data. Tahap adaptasi berlangsung selama 1 minggu yang bertujuan agar ternak dapat beradaptasi dengan pakan perlakuan, pengaruh pakan sebelumnya dan lingkungan. Tahap perlakuan dilakukan setelah tahap adaptasi dan dilaksanakan selama 1 minggu. Pemberian pakan sesuai dengan perlakuan masingmasing. Waktu pemberian untuk pakan konsentrat yaitu pukul 07.00 WIB dan pukul 14.00 WIB. Pakan hijauan diberikan pada pukul 09.00 WIB dan pukul 16.00 WIB, sedangkan air minum diberikan secara $a d$ libitum. 
Tabel 3. Komposisi ransum perlakuan dan kandungan nutrien ransum

\begin{tabular}{lrrr}
\hline \hline Bahan Pakan & \multicolumn{3}{c}{ Ransum Perlakuan (\%) } \\
\cline { 2 - 4 } & P1 & P2 & P3 \\
\hline Rumput Raja & 60 & 60 & 90 \\
Dedak padi & 29 & 19 & 29 \\
Ampas bir & 9 & 19 & 2 \\
Premix & 2 & 2 & 100 \\
\hline Jumlah & 100 & 100 & 11,02 \\
\hline Kandungan nutrien & & & 29,15 \\
PK & 9,27 & 10,15 & 5,04 \\
SK & 29,27 & 29,21 & 17,37 \\
LK & 4,80 & 4,92 & 37,42 \\
ABU & 15,57 & 16,47 & 51,96 \\
BETN & 41,09 & 39,25 & \\
TDN & 53,96 & 52,96 & \\
\hline
\end{tabular}

Tahap koleksi data dilakukan selama 10 hari. Pengambilan data konsumsi dilakukan dengan mencatat jumlah pakan yang diberikan dan sisa pakan setiap 24 jam. Konsumsi pakan dihitung dengan menimbang selisih antara pakan yang diberikan dengan sisa pakan setiap harinya. Pengambilan feses dilakukan empat kali pada pukul 06.00; $12.00 ; 18.00$ dan 24.00 WIB, Sampel feses dikomposit dan dihomogenkan. sehingga diperoleh sampel pakan, sisa pakan, dan feses untuk dianalisis proksimat.

Data parameter penelitian selanjutnya dilakukan analisis ragam untuk mengetahui adanya pengaruh perlakuan terhadap parameter yang diamati. Apabila analisis data menunjukkan adanya pengaruh nyata maka dilanjutkan dengan Uji Jarak Berganda Duncan's (Duncan Multiple Range Test/DMRT) (Steel dan Torie, 1995).

\section{HASIL DAN PEMBAHASAN}

Rerata PKdd, LKdd, SKdd, dan BETNdd domba ekor tipis yang diperoleh selama penelitian dapat dilihat pada Tabel 4 .

Hasil penelitian menunjukkan bahwa pemberian dedak padi dan ampas bir dengan rasio yang berbeda berpengaruh sangat nyata $(\mathrm{P}<0,01)$ terhadap nilai PKdd. Rasio pemberian 19\% DP dengan 19\% AB (P2) dan P3 (9\% DP dan 29\% AB menunjukkan nilai rata-rata $\mathrm{PKdd}$ yang lebih tinggi dibandingkan dengan P1 (29\% DP dan 9\% AB), tetapi antara rasio pemberian $\mathrm{DP}$ dan $\mathrm{AB}$ pada $\mathrm{P} 2$ dan P3 tidak menunjukkan perbedaan yang nyata.

Pemberian DP dan AB dengan rasio yang berbeda pada penelitian ini meningkatkan kandungan PK ransum. Kandungan PK pada ketiga ransum perlakuan yakni 9,27\%; 10,15\%; dan $11,02 \%$. Kandungan PK meningkat seiring banyaknya $\mathrm{AB}$ yang digunakan. Ampas bir merupakan bahan pakan sumber protein, sedangkan DP merupakan pakan sumber energi. Dijelaskan oleh Murni et al., (2008) ampas bir dalam kondisi segar memiliki kadar air yang tinggi dan merupakan bahan sumber protein dengan kandungan protein mencapai 21,4\%. Lebih lanjut dijelaskan oleh Agus (2012) bahwa dedak padi merupakan sumber energi bagi ternak dengan kandungan energi mencapai $2730 \mathrm{kkal} / \mathrm{kg}$.

Perlakuan P1 berbeda sangat nyata $(\mathrm{P}<0,01)$ dengan $\mathrm{P} 2$. Hal ini diduga karena peningkatan $\mathrm{PK}$ ransum ternak domba dapat meningkatkan aktifitas dan sintesis mikroba melalui penyediaan amonia yang merupakan hasil akhir degradasi PK ransum yang sifatnya 
Tabel 4. Rerata PKdd, LKdd, SKdd, dan BETNdd (\%)

\begin{tabular}{llll}
\hline \hline \multirow{2}{*}{ Peubah } & \multicolumn{3}{c}{ Rerata Perlakuan } \\
\cline { 2 - 4 } & P1 & P2 & P3 \\
\hline Protein kasar dapat dicerna (PKdd) & $6,71^{\mathrm{B}}$ & $7,64^{\mathrm{A}}$ & $8,12^{\mathrm{A}}$ \\
Serat kasar dapat dicerna (SKdd) & 14,92 & 16,00 & 16,50 \\
Lemak kasar dapat dicerna (LKdd) & $4,07^{\mathrm{B}}$ & $4,27^{\mathrm{A}}$ & $4,36^{\mathrm{A}}$ \\
Bahan ekstrak tanpa nitrogen dapat dicerna (BETNdd) & 24,92 & 25,11 & 22,37 \\
\hline
\end{tabular}

Keterangan: Nilai rerata yang bertanda huruf besar yang berbeda pada baris yang sama menunjukkan perbedaan sangat nyata $(\mathrm{P}<0,01)$

mudah larut, sehingga akan berdampak pada peningkatan kecernaan protein. Soebarinoto et al. (1991) menyatakan bahwa mikroba rumen mempunyai peranan penting dalam metabolisme protein karena dapat menggunakan Non Protein Nitrogen (NPN) untuk diubah menjadi protein tubuhnya. Peningkatan populasi mikroba rumen menyebabkan proses fermentasi dalam rumen meningkat, sehingga menyebabkan kecernaan protein juga meningkat. Ditambahkan oleh Soeharsono (2010) bahwa sekitar 50-60\% nitrogen yang diperlukan oleh induk semang dapat dipenuhi oleh mikroba rumen.

Perlakuan P2 tidak berbeda dengan P3 walaupun terjadi peningkatan PK dalam ransum. Kemungkinan ini disebabkan karena titik optimal penggunaan protein ransum berada pada taraf pemberian dedak padi $19 \%$ dan ampas bir 19\% (P2). Meningkatnya kadar protein dan degradasi protein ransum sering diikuti dengan meningkatnya konsentrasi $\mathrm{N}$ $\mathrm{NH}_{3}$ di dalam rumen (Davidson et al., 2003; Olmos Colmenero dan Broderick, 2003). Kelebihan $\mathrm{N}^{-\mathrm{NH}_{3}}$ dalam rumen jika tidak digunakan untuk sintesis protein mikroba akan diabsorbsi melalui dinding rumen dan diubah menjadi urea di dalam hati (Lobley et al., 1995) dan sebagian lagi hilang melalui urin. Jadi tingginya kadar protein ransum tidak selalu dapat dimanfaatkan secara optimal oleh ternak untuk meningkatkan produksi.

Serat kasar dapat dicerna (SKdd) merupakan hasil pencernaan SK yang terdapat dalam pakan yang diabsorbsi oleh dinding usus. Rerata SKdd pada pemberian DP dan
$\mathrm{AB}$ dengan rasio yang berbeda dari $\mathrm{P} 1$ sampai P3 adalah 14,92; 16,00 dan 16,50 \%. Hasil analisis variansi menunjukkan bahwa perlakuan $\mathrm{DP}$ dan $\mathrm{AB}$ dengan rasio yang berbeda tidak berpengaruh terhadap nilai SKdd. Artinya dengan pemberian DP dan AB dengan rasio yang berbeda tidak terjadi peningkatan maupun penurunan terhadap nilai SKdd. Kandungan SK dalam ransum perlakuan yaitu secara berurutan dari P1, P2, dan P3 adalah 29,27; 29,21; dan 29,15\%. Hal tersebut menyebabkan nilai SKdd yang hampir sama pula pada setiap perlakuan, yaitu 14,$92 ; 16,00 ; 16,50 \%$ (Tabel 4). Hal ini diduga peningkatan penggunaan $\mathrm{AB}$ tidak menurunkan kualitas fraksi serat dalam ransum. Maynard et al. (2005) yang menyatakan bahwa daya cerna serat kasar dipengaruhi oleh beberapa faktor antara lain kadar serat kasar dalam pakan, komposisi penyusun serat kasar dan aktifitas mikroorganisme. Dampak dari SK terhadap availabilitas nutrien pakan lebih terkait erat dengan efek negatif dari kecernaan semu nutrien lainnya dibandingkan dengan jumlah energi yang yang dihasilkan dari serat itu sendiri (Owens et al. 2010).

Menurut Wina dan Susana (2013) menyatakan bahwa kandungan lemak kasar didalam ransum dapat menurunkan kecernaan karbohidrat terutama keceraan serat. Keadaan ini berkaitan dengan lingkungan rumen yang kurang optimal bagi kehidupan mikrobia rumen. Hasil penelitian menunjukkan bahwa meningkatnya kandungan LK pada ransum tidak menganggu pencernaan SK. Kandungan 
LK pada ransum $\mathrm{P} 1, \mathrm{P} 2$, dan $\mathrm{P} 3$ sebesar 4,8; 4,$92 ; 5,04 \%$, kadar lemak ini tidak berpengaruh pada lingkungan rumen. Selanjutnya Wina dan Susana (2013) menambahkan lagi bahwa kebutuhan lemak pada ternak ruminansia tidak boleh terlalu tinggi (di atas 5\% dari total ransum).

Nilai LKdd sangat dipengaruhi $(\mathrm{P}<0,01)$ oleh rasio penggunaan $\mathrm{DP}$ dan $\mathrm{AB}$ dalam ransum. Rasio pemberian 19\% DP dan 19\% AB pada P2 dan perpaduan 9\% DP serta 29\% AB pada P3 menunjukkan nilai LKdd yang lebih tinggi dibandingankan P1, tetapi pemberian $\mathrm{DP}$ dan $\mathrm{AB}$ pada $\mathrm{P} 2$ tidak menunjukkan perbedaan dengan P3. Kandungan LK pada ransum perlakuan P1, P2, P3 yaitu 4,80; 4,92; 5,04\%. Semakin banyak penggunaan $A B$ dan semakin sedikit komposisi DP dapat menaikkan kandungan LK dan menurunkan SK ransum (Tabel 3). Nilai LKdd pada setiap perlakuan mengalami peningkatan dari P1, P2 dan P3 secara berturut-turut adalah 4,07; 4,27 dan 4,36\%. Hal ini sesuai pendapat Mubarok et al., (2013) bahwa berkurangnya kandungan SK dalam ransum ternak kambing dapat meningkatkan kecernaan LK. Jumlah konsumsi LK tiap perlakuan ditentukan oleh kandungan LK dalam ransum. Peningkatan kandungan LK dalam ransum pada level tertentu dapat meningkatkan konsumsi LK. Menurut Parakkasi (1999) penggunaan lemak dalam ransum dapat meningkatkan tingkat konsumsi. Apabila penambahan tersebut terlampau banyak akibatnya negatif terhadap tingkat konsumsi. Bahan pakan utama ruminan yaitu hijauan tidak banyak mengandung lemak, yaitu hanya sekitar 3\%. Angka konsumsi LK yang didapat pada masing-masing perlakuan tidak berbeda. Hal ini membuktikan bahwa penggunaan LK pada level 4,80-5,04 \% pada ransum tidak menyebabkan gangguan terhadap kecernaan LK. Sesuai dengan Wina dan Susana (2013) bahwa apabila kandungan lemak dalam ransum ternak ruminansia terlalu tinggi yaitu $>5 \%$ akan dapat menganggu proses pencernaan.

BETN merupakan karbohidrat mudah larut yang ada dalam pakan yang dapat diabsorbsi di usus halus. Hasil penelitian menunjukkan bahwa pemberian $\mathrm{DP}$ dan $\mathrm{AB}$ dengan rasio yang berbeda pada domba lokal jantan tidak berpengaruh terhadap $(\mathrm{P}>0,05)$ nilai BETNdd. Artinya pemberian DP dan AB dengan rasio berbeda tidak berpengaruh terhadap nilai BETN dapat dicerna.

Kandungan BETN pada ransum relatif sama yaitu pada P1, P2, P3 sebesar 41,09; 39,$25 ; 37,42 \%$. Hal tersebut akan menyebabkan konsumsi yang hampir sama pula pada setiap perlakuan. Kandungan BETN dan konsumsi yang hampir sama pada setiap perlakuan mengakibatkan kandungan BETNdd yang hampir sama pula di setiap perlakuan. Lebih lanjut dijelaskan oleh Budiman et al. (2006) bahwa komponen BETN terbesar adalah karbohidrat non struktural seperti pati, monosakarida atau gula-gula. Penggunaan ampas bir yang semakin meningkat sampai level 29\% dapat meningkatkan populasi mikroba rumen yang terlihat dengan adanya peningkatan nilai PKdd. Hal ini dapat membuktikan bahwa peningkatan bakteri rumen tidak mengganggu proses pencernaan BETN, yang ditandai dengan nilai BETNdd yang sama $(\mathrm{P}>0,05)$. Dijelaskan oleh Tillman et al. (1998) bahwa adanya peningkatan aktivitas mikroba dalam mendegradasi substrat, maka akan mempengaruhi juga pemakaian energi (BETN) yang menyebabkan menurukan kandungan BETN. Selanjutnya Owens et al (2010) menjelaskan bahwa tingginya kadar SK pakan akan mengakibatkan peningkatan kehilangan energi melalui feses (fecal energy) terutama pakan yang mengandung BETN yang tinggi. Namun respon seperti ini lebih terlihat pada pakan secara individu.

Rerata BOdd dan TDN domba ekor tipis yang diperoleh selama penelitian dapat dilihat pada Tabel 5 . 
Tabel 5. Rerata BOdd dan TDN (\%)

\begin{tabular}{lccc}
\hline \multirow{2}{*}{ Nilai BOdd dan TDN } & \multicolumn{3}{c}{ Rerata Perlakuan } \\
\cline { 2 - 4 } & P1 & P2 & P3 \\
\hline Bahan Organik dapat dicerna (BOdd) & 50,81 & 52,94 & 51,18 \\
Total digestible nutrient (TDN) & 55,71 & 58,35 & 56,79 \\
\hline
\end{tabular}

BOdd dan TDN akan memberikan nilai yang hampir sama ketika kandungan ransumnya berkadar LK yang rendah. Jika dilihat nilai Bodd dan TDN yang tidak begitu tinggi selisihnya maka keadaan ini menunjukkan bahwa kadar LK sudah cukup tinggi. Namun justru LK lebih berperan meningkatkan nilai energi daripada efek negatifnya terhadap lingkungan rumen. Peningkatan lemak ransum mampu memperbaiki LKdd jd perbedaan BOdd dan TDN juga dipengaruhi oleh kualitas atau komponen penyususn lemak pakan.

Total Digestible Nutrient (TDN) merupakan gambaran dari total energi yang berasal dari pakan yang dikonsumsi oleh ternak. Pemberian $\mathrm{DP}$ dan $\mathrm{AB}$ dengan rasio yang berbeda pada domba lokal jantan tidak berpengaruh terhadap nilai TDN $(\mathrm{P}>0,05)$. Artinya dengan rasio perpaduan dedak padi dan ampas bir yang digunakan tidak terjadi peningkatan nilai energi yang dilihat dari nilai TDN.

Nilai TDN berhubungan erat dengan bahan organik dapat dicerna (BOdd). BOdd merupakan gambaran ketersediaan nutrien dalam pakan yang dapat dicerna. Nilai BOdd pada penelitian berturut-turut pada $\mathrm{P} 1, \mathrm{P} 2$, dan P3 adalah 50,81; 52,94; 51,18\% (Tabel 5). Nilai BOdd yang relatif sama mengakibatkan nilai TDN yang hampir sama pula pada setiap perlakuan. Hal ini sesuai dengan pendapat Luthfinanto et al. (2011) bahwa besar kecilnya nilai TDN bergantung pada kecernaan bahan organik dari pakan.

Daya cerna suatu bahan makanan tidak hanya dipengaruhi oleh komposisi suatu pakan tetapi juga dipengaruhi komposisi suatu makanan yang lain yang ikut dikonsumsi bersama pakan tersebut. Setiap bahan makanan mungkin mempengaruhi daya cerna bahan lain. Hal ini dapat dilihat pada tabel 4, walaupun nilai PKdd serta LKdd mengalami kenaikan dari P1 sampai P3. Nilai TDN pada penelitian ini tidak mengalami kenaikan yang diakibatkan nilai dari SKdd dan BETNdd yang tidak berbeda pada setiap perlakuan.

TDN merupakan gambaran penyediaan energi oleh ransum bagi ternak yang diperlukan bagi pertumbuhan mikroba rumen dan induk semang. Dijelaskan oleh Tilman et al. (1998) bahwa TDN merupakan BO pada bahan pakan yang dimanfaatkan sebagai energi bagi mikroba rumen dan tubuh ternak. Nilai TDN pada P1, P2 dan P3 secara berturut-turut adalah 55,71; 58,35 dan 56,79\% (Tabel 5). Nilai TDN yang sama menunjukkan bahwa pada ketiga ransum perlakuan memiliki kualitas energi yang sama, sehingga kemapuan menyediakan energi bagi mikrobia maupun tubuh ternak sama pula. Ke3 ransum perlakuan atau penggunaan $\mathrm{DP}$ dan $\mathrm{AB}$ pada berbagai rasio mempunyai potensi yg sama dlm menyediakan energi bagi ternak.

\section{KESIMPULAN}

Kesimpulan yang diperoleh dari penelitian yaitu pemberian dedak padi dan ampas bir pada lomba lokal jantan yang memberikan hasil terbaik pada level 19\% dedak padi dan $19 \%$ ampas bir.

\section{DAFTAR PUSTAKA}

Agus, A. 2008. Membuat Pakan Ternak Secara Mandiri. PT Citra Adi Parama. Yogyakarta.

Andriyani, A. K. 2006. Pengaruh Penggunaan Ampas Bir dalam Ransum terhadap 
Peforman Kelinci New Zealand White Jantan. Skripsi. Fakultas Pertanian. Universitas Sebelas Maret. Surakarta.

Anggorodi, R. 1990. Ilmu Makanan Ternak Umum. Gramedia, Jakarta

Ashes, J. R., B. D. Gulati, S. K. Cuthbertson dan T. W. Scott. 1992. Incorporation of W-3 Fatty Acid Oil Tissue and Serum Lipids of Ruminants. Lipids. 27:629-631.

Balai Pengkajian Teknologi Pertanian (BPTP). 2011. Jerami Padi Sebagai Bahan Organik di Lahan Sawah. Leaflet. Jawa Barat.

Blakely, J. dan D. H. Bade. 1998. Ilmu Peternakan. Gadjah Mada University Press, Yogyakarta.

Creswell, D. 1987. A Survey of Rice Byproducts From Different Countries. In: New Developments in Feed and Technology (Editor: D. Creswell). Monsanto Technical Symposium. Bangkok. Pp 4-35.

Djajanegara, A. 1999. Local Livestock Feed Resources. In: Livestock Industries Of Indonesia Prior To The Asian Financial Crisis. Rap Publication 1999/37 : 29-39.

Direktorat Jenderal Peternakan. 2007. Statistika Peternakan 2007. Direktorat Jenderal Peternakan Departemen Pertanian RI, Jakarta.

Frandson, R. D. 1996. Anatomi dan Fisiologi Ternak. 4th Edition. Gadjah Mada University Press, Yogyakarta. (Diterjemahkan oleh B. Srigandono dan K. Praseno).

Hartini, S. 2008. Pengaruh Penggunaan Ampas Bir dalam Ransum Terhadap Kecernaan Bahan Kering dan Bahan Organik Pada Domba Lokal Jantan. Skripsi. Fakultas Pertanian. Universitas Sebelas Maret. Surakarta.

Kamal, M. 1994. Nutrisi Ternak I. Laboratorium Makanan Ternak. Jurusan Nutrisi dan Makanan Ternak.
Fakultas Peternakan. Universitas Gadjah Mada.

Kartadisastra, H. R. 1997. Penyediaan dan Pengelolaan Pakan Ternak Ruminansia. Kanisius. Yogyakarta.

Kearl, L. C. 1982. Nutrition Requirements of Ruminants in Developing Countries. International Feedstuff Utah Agriculture Experiment Station. 1stEd. Utah State university, Logan.

Mirnawati dan G. Ciptaan. 1999. Pemakaian Empulur Sagu (Metroxylon, sp) Fermentasi dalam Ransum terhadap Retensi Nitrogen dan Rasio Efisiensi Protein pada Ayam Broiler. J. Peternakan dan Lingkungan. 5(01): 812.

Murni, R., Suparjo, Akmal, dan B. L. Ginting. 2008. Buku Ajar Teknologi Pemanfaatan Limbah Untuk Pakan. Laboratorium Makanan Ternak. Fakultas Peternakan. Universitas Jambi. Jambi.

Obst, J. M. 1978. Nilai Nutrisi Rumput Gajah sebagai Ransum Dasar untuk Pertumbuhan Domba di Indonesia. Bogor: Fakultas Peternakan IPB.

Owens, F.N., D.A. Sapienza and A.T. Hassen. 2010. Effect of nutrient composition of feeds on digestibility of organic matter by cattle: A review. J. Anim. Sci. 2010. 88 (E. Suppl.) : E151-E169 doi:10.2527/jas.2009-2559.

rawoto, J. A., C. M. S. Lestari, dan E. Purbowati. 2001. Keragaan dan Kinerja Produksi Domba Lokal Jantan yang Dipelihara Intensif dengan Memanfaatkan Ampas Tahu sebagai Pakan Campuran. Abstrak Hasil-Hasil Penelitian Tahun 1998/1999. Lembaga Penelitian Universitas Diponegoro. Semarang. Hal 68-70 (Abstr).

Preston, T. R., dan R. A. Leng. 1987. Matching Ruminant Production Systems with Available Resources in 
The Tropics and Subtropics. Penambul Books Ltd., Armidale NSW.

Purbowati, E. 2007. Kajian Perlemakan Karkas Domba Lokal dengan Pakan Komplit dari Jerami Padi dan Konsentrat pada Bobot Potong yang Berbeda. Program Pasca Sarjana Universitas Gadjah Mada, Yogyakarta. (Disertasi Doktor Ilmu Ternak).

Ranjhan, S. K. 1997. Animal Nutrotion and Feeding Practice In India. Vikan Pub. House PVT Ltd, New Delhi.

Rosningsih, S. 2000. Pengaruh Lama Fermentasi dengan EM-4 Terhadap Kandungan Nutrien Ekskreta Layer 1 (2): 62-69. Buletin Pertanian dan Peternakan. Fakultas Peternakan Universitas Wangsa Manggala. Yogyakarta.

Rusyad, A. 1977. Sheep breeds of Indonesia. Report for FAO/UNEP Project "Conservation of Animal Genetic Resources". pp: 10.

Scott, M. L, M. C. Neisheim dan R. J. Young. 1982. Nutrition of Chiken. 3rd Edition, Published M, L Scott and Associates: Ithaca, New York.

Siregar, S. B. 1994. Ransum Ternak Ruminansia. Penebar Swadaya. Jakarta.

Soebarinoto, S. Chuzaemi, dan Mashudi. 1991. Ilmu Gizi Ruminansia. Jurusan Nutrisi dan Makanan Ternak Fakultas Peternakan Universitas Brawijaya. Malang.

Soenarjo, E., D. S. Damardjati dan M. Syam. 1991. Padi Buku 3 . Badan Penelitian dan Pengembangan Pertanian. Pusat Penelitian dan Pengembangan Tanaman Pangan. Bogor.

Steel, R. G. D. dan J. H. Torrie. 1995. Prinsip dan Prosedur Statistik. Terjemahan: B.Sumantri. PT Gramedia Pustaka Utama, Jakarta.
Stokishcs. 2013. Fermentasi Jerami dengan SOC. http://www.stokishcs.com/ Pada Bulan Ferbruari 2015.

Sugeng, B. 2003. Sapi Potong. Penebar Swadaya. Jakarta.

Sunarso, S. 1980. Pengaruh Tingkat Pemberian Bekatul dalam Ransum terhadap Berat Karkas Domba Lokal Jantan. Bogor: P3T Ciawi-Bogor.

Sutama, I. K dan IGM Budiarsana. 2010. Panduan Lengkap Kambing dan Domba. Penebar Swadaya, Jakarta.

Suwandi, 2007. Peranan Mikroba Rumen pada Ternak Ruminansia. Balai Peneliti Ternak. Ciawi.

Tillman A. D., H. Hartadi, S. Reksohadiprodjo, S. Prawirokusumo dan S. Lebdosoekotjo. 1989. Ilmu Makanan Ternak Dasar. Gajah Mada University Press. Yogyakarta.

Valentine, S. C. dan R. B. Wickes. 1982. The Production and Composition of Milkfrom Dairy Cow Feed Hay and Suplemented with Either Brewers Grains or Rolled Barley Grain. Australian J. Exp. Agr. Husb 22: 155158.

Van Soest, P. J. 1982. Effect Of Environment And Quality Fibre On The Nutritive Value Of Crop Residues. In: Plant Breeding And The Nutritive Value Of Crop Residues. Reed, J.D., B.S. Capper And P.J.H. (Eds.). Adis Ababa, Ethioppia. Ilca. Pp. 71-96.

Widyawati, S. D., W. P. S. Suprayogi dan R. Utomo. 2011. Percepatan Penggemukan Ternak Sapi Melalui Suplementasi Sumber Protein dengan Metode Slow Released-Ammonia. Laporan Penelitian Hibah Pekerti. Fakultas Pertanian, Universitas Sebelas Maret. Surakarta.

Winarno, F. G., S. Fardiaz, dan D. Fardiaz. 1980. Pengantar Teknologi Pangan. PT Gramedia. Jakarta. 